\title{
Public Perception and Attitude towards Value Added Tax (VAT) in Nigeria
}

\section{Adesina Olugoke Oladipupo, Famous Prince Izedonmi}

Department of Accounting, University of Benin, Benin City, Nigeria.

Email: sinaoladipupo@yahoo.com,sina.oladipupo@uniben.edu

Received July $16^{\text {th }}$, 2013; revised August $15^{\text {th }}$, 2013; accepted September $13^{\text {th }}, 2013$

Copyright (C 2013 Adesina Olugoke Oladipupo, Famous Prince Izedonmi. This is an open access article distributed under the Creative Commons Attribution License, which permits unrestricted use, distribution, and reproduction in any medium, provided the original work is properly cited.

\begin{abstract}
This study assesses the level of tax education, particularly the level of understanding of VAT law amongst three categories of taxpayers in Nigeria. The data for the study were collected by means of structured questionnaires administered to the respondents. The analysis of results showed that most of the respondents have poor knowledge of VAT law in Nigeria, irrespective of their level of literacy, and that there was no significant difference in the amount of knowledge of VAT law amongst the three groups of respondents used for the study. A suggestion was made of an aggressive and widespread public education on VAT matters that could involve an integration of tax education into the curricula of education in our institutions of higher learning and general public enlightenment through media, and organized workshops for specific groups.
\end{abstract}

Keywords: VAT; VATable Goods; Tax Education

\section{Introduction}

Public attitude towards tax matters has often been negative. In the early times, taxation was to a large extent considered as an instrument of oppression wielded by the ruling class over the subjects. Reference [1] observed that the power to impose tax belongs to the government, and could only be curtailed by express constitutional provisions. But as the Government has an inherent right to impose tax on citizens, the citizens also have an inalienable right over their property and would not like to part with such to government, which is often seen as an inanimate, detached and remote entity. It is the constitutional duty of the citizens to pay any tax that might be imposed by Government.

However, no citizen would like to pay any tax voluntarily and that is why Government usually enacts law to back it up. A typical tax law would specify the purpose of the tax, the mode of its administration, scope, offences and associated penalties relating to the tax matters. The essence of the tax law is to assist taxpayers and tax administrators to know what the tax is all about, how it works, who is responsible for its administration as well as the offenders relating to tax matters and associated penalties etc.
Every citizen is required to be conversant with the tax laws in operation. Such knowledge or awareness has the tendency to promote voluntary tax compliance amongst the citizenry. Even for those that operate trans-border transactions, they are equally expected to know, understand and comply with other relevant tax laws of foreign countries, as they affect their business operations. The mere fact that somebody has been educated does not imply that he/she may have sufficient knowledge in tax matters. This may even be true for professionals as well as laymen. Sometimes citizens are trapped by the elegance of this assumption. Therefore, the following questions provide a clear focus for our current study. Do businessmen or professionals or even the laymen really know and understand various tax laws in operations? How much of the tax laws do they know? And does the knowledge of tax laws vary from one group of taxpayers to another? Does general education guarantee taxpayers' understanding of tax laws? Does the taxpayers' knowledge of tax laws influence their activities? How can the differences in taxpayers' knowledge of tax laws help in the planning and implementation of tax laws?

It is in an attempt to provide empirical answers to the above questions and other related issues that this study 
was undertaken. Towards this end, the focus of this study is on the recently promulgated tax laws in Nigeria, particularly the Value Added Tax (VAT), which came into operation in 1993.

The objectives of this study are:

1) To assess the level of awareness and understanding of VAT by businessmen, professionals and laymen.

2) To assess the relative impacts of VAT on the VAT payers and the economy.

3) To identify the problems confronting the administration of VAT from the perspective of the respondents.

The two hypotheses formulated for testing in this study are stated below:

1) That there are differences in the knowledge of VAT amongst the businessmen, professionals and laymen.

2) That there is positive relationship between the level of formal education of a taxpayer and his level of knowledge of VAT law.

\section{Theoretical Framework and Review of Literature}

Much has been written on Value Added Tax (VAT) since its inception in tax administration worldwide. As per the conceptual meaning of VAT, opinions differ. Reference [2] regards VAT as "a tax levied at each stage of production on the first value added". Reference [3] on the other hand considers VAT as a multi-stage consumption tax levied on the difference between a firm's sales and the value of its purchased inputs used in producing goods". But the most widely accepted but wooly definition is the one provided by the United Kingdom Statement of Standard Accounting Practice (SSAP) Number 5, which states "VAT is a tax on the supply of goods and services, which is eventually borne by the final consumer but collected at each stages of the production and distribution chain" [4].

From these definitions, it is evident that the classical VAT is a consumption tax, its incidence is on the final consumers and it is a multi-state collection tax. The original form of VAT started in Germany in 1919. In 1937, France introduced a form of VAT known as production tax, which has helped replaced with producer's income-based tax in 1948 and consumption tax in 1954. The French VAT system became a condition precedent of becoming a member of European Economic Community (EEC) under the treaty of Rome in 1957. The European community unanimously adopted VAT in 1967 following the reports of the Neumark and Jansen Committees. Nigeria also adopted VAT in 1993. Many other countries have come to replace sales tax with VAT for certain reasons. VAT is more comprehensive and well equipped for taxing, more equipped to ensure voluntary compliance for its multi-stage collection and credit mechanism through the use of invoices, it also provides a well-defined audit-trail for tax authorities and thus it is easier to integrate VAT with income tax audit.

VAT has some characteristics, which include neutrality, equity, and regressive nature. VAT is neutral to foreign trade; individual or household choices; individual or household savings and consumption decisions; forms of business ownership; mode of financing and the choice amongst inputs except where the supplies are VAT exempt or zero-rated. The argument on the equity of VAT based on the Hobbies theory of equity, which states that the people should pay tax based on what they withdraw from society's resources, as measured by consumption, rather than what they contribute to such resources, as measured by income [5]. The equity of VAT is therefore based on the fact that it is a consumption tax. The regressive characteristics of VAT has been argued that it is only in a short run period; say a year that VAT is regressive. However, on life cycle concept VAT burden tends to even out in the long run.

The strategic policy decisions in establishing VAT systems have attracted of tax scholars such as [6]. According to him some of these strategic policy decisions range from the desirability of VAT adoption or otherwise, the form of VAT system to adopt, coverage of VAT system, the government department to be responsible for VAT administration. On the desirability of VAT, two groups exist. There are those countries, which adopted it on a mandatory platform either because it was a condition precedent to becoming a member of a regional grouping, like EEC or because of the linkage with the colonial French master, as Cote d'Ivoire and Senegal. Then there are other countries, which were merely persuaded to adopt VAT systems as a means of enhancing their revenue-base by such international bodies as World Bank, International Monetary Fund (IMF). Examples of which is Nigeria. VAT system has not in any way been attractive in some other countries particularly those with strong pure federation. In these countries, sales tax was doing very well and that each component state is seriously guarding its revenue-base as well as its relative independence more jealously. Examples of such countries include United States of America and Canada. Three methods for calculating VAT have been identified. These are the credit method (the Japanese model) and the addition and subtraction methods respectively. The credit method is the most popular even though it does not define value added. The attractions include easy policing and affordability of good audit trail due to the use of invoicing.

VAT verification has two forms, namely the room (or office) verification and the field verification. The aim of VAT verification is to promote enforcement of tax laws while VAT audit aims at minimizing tax evasion. VAT audit could be simple or in-depth audit. However, an 
effective VAT audit requires planning, audit strategies and audit programme, and audit checklist. It has been suggested that VAT audit system should be integrated with the income tax audit; an effective tax audit system enhances the level of the tax compliance. VAT investigation is usually upon the suspicion of criminal tax fraud or tax evasion. Tax fraud has three elements, namely, the action, the consequences and accountability. There are numerous acts, which could amount to tax fraud. These include failure to register, unreported sales or purchases, misuse or use without right of a taxpayer's invoice; and exaggerated refund claims. Others are omission of selfdelivers; incorrect description or classification of goods in a multiple rates system, falsification of books, records and other documents and presentation of score as if they are genuine; failure to show or submit books, records and other documents, to failure to pay tax already withheld etc. Any of these categories of persons could be liable for criminal tax fraud: VAT payers, a representative of a firm (such as the director, secretary or a manager) an authorized person (proxy), and an employee of the taxpayer. Penalties exist for various offences of VAT laws. These range from payment of fine (either of specific sum of money or a certain percentage of amounts of tax lost to the governments as a result of the acts of tax evasion) to imprisonment [7].

\section{An Overview of VAT Law in Nigeria}

VAT was introduced in Nigeria in 1993 to replace the then existing sales tax. Some Unity Party of Nigeria's (UPN) controlled states as a means of enhancing their revenue base to carry out their free education introduced sales tax in Nigeria in 1980-1981 and free health services programmes. Attempt at forestalling State Governments from legislating on tax matters proved abortive at the Lagos State then argued that only income taxation was in the exclusive legislature list and as such any state could legislate on sales, purchase and consumption taxes. This bold move of Lagos State Government prompted many other states in Nigeria to join. Hence by 1986 many states in Nigeria had adopted sales tax through their various states edicts.

The widespread adoption of sales tax by many states lacked harmonious structure with attendant negative implications on inflow of foreign-investment and distribution of industries in Nigeria. The Federal Government came up with Sales Tax Decree Number Seven of 1986 to harmonize the sales tax structure while leaving the implementation in the hands of the states on the basis of residence. In spite of the opposition by the states on the unconstitutionality of the Federal Government action, the latter did not stop in that by 1991 a study group was set up to review the entire tax system in Nigeria. The study group proposed VAT but suggested a modified Value
Added Tax (MVAT) for Nigeria. Sales Tax was finally replaced in 1993 with VAT after promulgation of relevant legislation. Some of the reasons adduced for the replacement of sales tax with VAT include: that sales tax base was too narrow as the Sales Tax Decree targeted only locally manufactured goods and that VAT was capable of yielding high revenue compared to sales tax.

The VAT Decree came into force on 1st December 1993. The Decree was divided into six parts containing 43 sections and three schedules. Part one consisted of six sections, all devoted to definitions of terms. Section five provides guideline on the determination of the values of taxable goods and services, whether supplied for money consideration or non-monetary consideration or imported. Part two considered the Administration and Management of VAT. The Federal Board of Inland Revenue (FBIR) is responsible for the assessment and collection of VAT, registration of taxable persons and for accounting for VAT proceeds [8]. Issue of returns, remittances, recovery and refund of VAT is the subject of part three. It is the duty of the taxable person to take adequate records and accounts of all transactions, and to render returns of all goods and services purchased or supplied during the month on or before the 14th day of the following month. Part four provides for the Value Added Technical Committee. Sections 17 to 20 specified the composition, functions, proceedings and staffing of the committee, which is to provide technical, professional and advisory services on VAT matters to the Board.

Part five provided a list of offences and penalties associated with VAT. The offences range from furnishing false documents with a fine of twice the amount under declared if convicted to failure to submit returns to the Board with a fine \$5,000 for every month of default. The last part considered miscellaneous issues such as powers of Secretary or Minister of Finance to vary schedules and tax rate, inspection by an authorized officer, distribution of revenue amongst the tiers of government etc.

Reference [9] considered the perception of Nigerian businessmen on Value Added Tax (VAT). The study was carried out in city of Calabar, Cross River State, Nigeria. The types of business covered include distribution, consultancy services, manufacturing, importation, warehousing and advertising. Analysis of the data obtained from questionnaire administration showed that about 66.7 percent of the businessmen involved in the study claimed to be aware of VAT, although their knowledge is rather shallow. Only about 2.2 percent of the sampled businessmen registered for VAT. This probably could amount to high degree of incidence of VAT evasion and the concomitant loss of VAT revenue to government. Quite very few (about 1.7\%) of businessmen under study have ever attended business workshops/seminars where informa- 
tion and matters about VAT were being discussed. It was concluded that most businessmen in Nigeria are not well educated about VAT matters. VAT was considered as disincentive to most businessmen under study. They argued that most VATable products attract higher prices (because of VAT inclusion) and this is responsible for low sales compared to non-VATable products.

Reference [10] studied the impact of VAT on the economy. It was observed that VAT has the tendency to boost the revenue generating capacity of the economy and thus help the Nigerian economy to be less dependent on petroleum resources. Although VAT has the tendency of increasing the prices of goods and services that arc VATable, if the VAT proceeds are channeled to the provision of social infrastructure, the welfare of the citizenry would improve.

Reference [11] examined the administration of Value Added Tax (VAT) in the manufacturing industry in Nigeria. The objectives of the study were to determine the level of compliance and the effects of VAT on the internal operations of the manufacturing organizations. The data for the study were obtained from Bendel Feeds and Flour Mills, Ewu, Edo State. The results of the analysis showed that the company maintained high degree of compliance with the stipulation of VAT Decree. The study revealed that the VAT violates the tax canon of equity. It was argued that the imposition of flat rate of $5 \%$ on all organizations is unfair. It was claimed that companies that manufacture products, which are harmful to health such as cigarettes, tobacco and liquor, should be taxed at a higher rate. The flat rate of VAT makes the incidence of burden to be heavier on small companies that are striving to survive compared to the big and successful ones. The major shortcoming of this study is that it is limited in scope as it was limited to only one manufacturing company. We believe that the results could be more interesting if more manufacturing companies across diverse geo-political zones in the country are involved in the study.

Reference [12] examined the problems and prospects of VAT in Nigeria. Questionnaires were administered to the general public, suppliers of VATable goods and services and VAT Directorate of the Federal Inland Revenue Services. The results of the study revealed that majority of the respondents are not aware of VAT and had wrong notion about it. Many did not know VATable goods and services, as the lists are not commonly available. Many small-scale business owners have the habit of not keeping proper books of accounts while some medium-scale business are guilty of under invoicing. Some other problems identified by the study include late remittance of VAT collected, ineffective VAT collection system, poor coverage, fraud and unstable sharing formula. The study disclosed that VAT has really helped to increase the non-oil revenue locally generated by government. It was concluded that much has to be done in the area of publicity to raise the level of awareness of the public to the desired level.

Reference [13] looked at the understanding of the professional men about provisions and operations of the VAT law in Nigeria. Questionnaires were administered on professional men like Accountants, Lawyers, Medical Doctors, Engineers, Architects and Bankers, to determine how much they know about VAT law. The results of the study showed that most professional men participated in the study claimed that they are aware of VAT law and VAT operation in Nigeria. However, deeper probe into how much of the VAT law they know showed that most of them have shallow knowledge of VAT law. Many have not even seen a copy of VAT law before let alone reading and understanding what the law says in detail.

The few accountants (25\%) and lawyers (15\%) who demonstrated knowledge of VAT law to some extent happened to be those who practice as tax management consultants. The rest who had no course to deal with VAT law in general have no detailed knowledge of it. Thus, it is practically difficult for them to assess the adequacy or otherwise of the law.

Reference [14] carried out a similar study in 1999. She examined the perception of the tax consultants on the adequacy or otherwise of VAT law in Nigeria. Questionnaires were administered to tax consultants in eight cities in Nigeria, namely, Ibadan, Benin City, Akure, Asaba, Kaduna, Kano, Calabar and Enugu. One of the major objectives of the study was to compare the legal expectations of VAT with what actually obtains in practice. Majority of the tax consultants used for the study (78\%) claimed to have read VAT Decree. About 98\% of those who claimed to have read VAT decree also said that they understood it. As a test of their knowledge and understanding of VAT they were demanded to outline the contents, the striking issues, and loopholes (if any) in the VAT decree. Unfortunately, over $80 \%$ of those who claimed to understand VAT decree could not outline the contents and neither were they able to identify any striking issues nor any loopholes.

Reference [15] examined the impacts of VAT on buying behaviour of consumers of VATable goods in supermarkets in Benin City. The study aimed at determining whether imposition of VAT on goods and services influence the choice of consumers, whether VAT affects consumer's taste and preference, for VATable supermarket goods. Two sets of questionnaires were administered separately to selected consumers of supermarket goods and owners of supermarkets in Benin City. The data obtained were analyzed and the results showed that most of the consumers of supermarket goods are not aware whether they purchased VATable goods or not. 
The implication of this is that imposition of VAT on those supermarket goods has no negative effects on consumers' choices as well as their taste and preference. The owners of supermarkets observed that the imposition of VAT makes the costs of VATable supermarket goods more expensive than non-VATable ones and thereby makes sales of VATable supermarket goods less. Owners of supermarkets observed that customers must have resorted to buying those goods that they used to buy from the supermarkets before imposition outside the supermarkets. The implication of this is that consumers are likely prone to buy fake and adulterated goods outside supermarkets because of their cheapness. However, this point cannot be substantiated, as the fact that goods sold in supermarkets need not be superior to similar ones sold outside the supermarkets. This has necessitated the design of an on-going detailed study on the analysis of sales of VATable goods in supermarkets before and after the introduction of VAT in Nigeria (in progress). It is expected the results of this study will throw more light on the impact of VAT on consumers' behaviour in Nigeria.

Reference [16] examined value added tax (VAT) and economic growth of Nigeria. Using time series data on the gross domestic product (GDP), VAT revenue, total tax revenue and total (Federal Government) revenue from 1994 to 2008, the results showed that VAT revenue accounted for about 95\% significant variations in GDP in Nigeria. It was observed that VAT revenue was more stable than GDP during the period but no causality existed between the GDP and VAT revenue. It was the recommended that all administrative loopholes in the management of VAT matters in Nigeria should be addressed to enable VAT revenue to continuing to contribute significantly to the economic growth in Nigeria.

In another related study on the impact of VAT on revenue generation in Nigeria, it was observed that VAT has statistically significant effect on revenue generation in Nigeria. Honest dedication of all agents of VAT for collection and payment improvement in the collection of VAT by government were then advocated [17]. Realizing the significant contribution of VAT on the economic growth in Nigeria, it was recommended that government should sensitize the people to enable it increase the tax rate so as to enlarge its annual revenue for economic development [18].

From the foregoing, it is evident that VAT contributes significantly to the total revenue collectable by governments in Nigeria. In spite of this, there are still problems associated with VAT payment by the public. Should Nigerian government decide to increase VAT rate to enlarge her revenue base because of the effect of VAT revenue on government total revenue? How would the public react? To be able to preempt what would be the public reaction on such a proposed public policy, it is important to know what is the current public perception and attitude to VAT system in Nigeria. This is the rationale behind this study.

\section{Materials and Methods}

All taxpayers in Nigeria constitute the target population for this study. However, for comparative analysis we decided to structure the taxpayers into groups, namely, general businessmen, the professionals and others, which we referred to in this study as laymen. The fieldwork for the study was carried out in cities selected from the three geo-political zones in Nigeria to ensure adequate representation of samples to be collected. These are Benin City, Warri, Lagos, Ibadan in the Southwest, Enugu, Aba, and Port Harcourt in the Southeast, and Kaduna and Kano in the North. Using stratified random sampling technique one hundred (100) questionnaires were administered to each of the three categories of taxpayer or strata mentioned above in each city. Thus, a total of three hundred (300) taxpayers were sampled in each city to give a total of 2700 taxpayers, which participated in the study.

Each questionnaire administered consisted of four different sections. The first section elicits general information about the respondents. Such information includes the sex, age, marital status, educational status, occupation and income of the respondents. The second section dwells on the awareness of VAT law amongst taxpayers while the third section considers their understanding of VAT's operation. The last section presents an opportunity for the respondents to consider the impacts of VAT on taxpayers in particular and Nigerian economy in general.

The data obtained from the study were analyzed using descriptive statistical techniques such as the frequency distributions and measures of central tendency. Two hypotheses were formulated for the study. The first hypothesis states that there are differences in the knowledge of VAT amongst the businessmen, professionals and laymen. This hypothesis was tested using chi-square analysis. The second hypothesis states that there is positive relationship between the level of formal education of a taxpayer and his level of knowledge of VAT law. The hypothesis was tested using the Spearman rank correlation analysis. The results of these hypotheses testing are indicated in appropriate sub-section below.

\section{Results and Discussion}

Out of the total of 2700 taxpayers engaged in the study only 1467 taxpayers responded to our questionnaires. This represents slightly above $54 \%$ of the taxpayers. The breakdown of the 1467 taxpayers that participated in this study is presented in Table $\mathbf{1}$. 
Table 1. Sex distribution of respondents.

\begin{tabular}{ccccccc}
\hline & \multicolumn{2}{c}{ Males } & \multicolumn{2}{c}{ Females } & \multicolumn{2}{c}{ Total } \\
\hline Group & No. & $\%$ & No. & $\%$ & No. & $\%$ \\
\hline Professionals & 225 & 22 & 198 & 42 & 423 & 29 \\
Businessmen & 486 & 49 & 90 & 19 & 576 & 39 \\
Laymen & 288 & 29 & 180 & 39 & 468 & 32 \\
Total & 999 & 100 & 468 & 100 & 1,467 & 100 \\
\hline
\end{tabular}

Source: Authors (2013).

We observed that many Businessmen (39\%) participated in the study compared to the Professional (29\%) and Laymen (32\%). Similarly, more males (999 males or $68 \%$ ) responded to our study than women (468 females or $32 \%$ ). All the respondents were Nigerians. They belonged to different ethnic groups such as Yoruba, Hausa, Igbo, Bini, Urhobo, Afemai, and Isoko. The average age of the Professional group was 31 years. About $63 \%$ of these people were married while $37 \%$ were single. The professionals included Engineers, University Lecturers, Teachers, Accountants, Bankers, Medical Doctors and Nurses. By virtue of their background they are highly certificated people. The second group included men and women operating their personal businesses. The average age of the people in this group was 40 years. Majority of these people were married (about 60\%). Most of them possessed primary or secondary school certificates (78\%) while the rest possessed either non-degree post-secondary school certificates (about $10 \%$ ) or degree post-secondary school certificates (about 2\%). The third group consisted the laymen, majority of who are into public service $(70 \%)$ and about $12 \%$ were unemployed. Majority of them had post-secondary school (non-degree) certificates (39\%) while the rest either had secondary school certificates (29\%) or first-degree certificates $(19 \%)$ or post-graduate certificates (13\%). No stark illiterate person educationally participated in the study.

\section{Awareness of VAT and VAT Law}

The major assumption of this is that tax compliance depends on the taxpayers' awareness, knowledge and understanding of the applicable tax law. In this study, attempt was made to ascertain the veracity of this assumption. Table 2 shows the variation in the proportion of respondents who claim to be awared of general issues related to VAT, VAT law, and its operation in Nigeria end those who do claim not to be aware.

From the above it is evident that about 79\% (1152) respondents claimed that they are aware of VAT while $21 \%$ (315) indicated ignorance or simply refused to respond. More of Businessmen indicated awareness than the Professional and Laymen. More of laymen indicated lack of awareness relative to other groups. However, only $2 \%$ of the professional men, $15 \%$ of the businessmen and $6 \%$ of the laymen, could provide correct definitive meaning of \%'AT. They simply described VAT as a consumption tax payable on goods and services, which were used to replace tax in 1994 (See Table 3).

Majorities of the respondents have wrong knowledge of what VAT is all about. Table 4 summarizes the various ways the respondents have described VAT wrongly.

We observed that most of the respondents (44\%) did not know VAT more than simply Value Added Tax. Similarly, small proportion of the professional men (28\%), Businessmen (17\%) and Laymen (17\%) agreed that

Table 2. Awareness of VAT, VAT law and its operation in Nigeria.

\begin{tabular}{ccccc}
\hline \multirow{2}{*}{ Group } & \multicolumn{2}{c}{ Aware } & \multicolumn{2}{c}{ Not aware } \\
\cline { 2 - 5 } & No. & $\%$ & No. & $\%$ \\
\hline Professional & 360 & 31 & 63 & 20 \\
Businessmen & 468 & 41 & 108 & 34 \\
Laymen & 324 & 28 & 144 & 46 \\
Total & 1152 & 100 & 315 & 100 \\
\hline
\end{tabular}

Source: Authors (2013).

Table 3. Respondents' knowledgeability of VAT.

\begin{tabular}{ccccc}
\hline \multirow{2}{*}{ Group } & \multicolumn{2}{c}{ Aware } & \multicolumn{2}{c}{ Not aware } \\
\cline { 2 - 5 } & No. & $\%$ & No. & $\%$ \\
\hline Professional & 9 & 2 & 414 & 98 \\
Businessmen & 90 & 15 & 486 & 85 \\
Laymen & 27 & 6 & 441 & 94 \\
\hline
\end{tabular}

Source: Authors (2013).

Table 4. Some ways taxpayers described VAT.

\begin{tabular}{cccc}
\hline S/No. & Incorrect responses & \\
\hline 1 & It is tax charged on consumer products & 207 & 15 \\
2 & It is tax paid on goods & 162 & 12 \\
& It is tax paid for consuming luxury goods & 99 & 7 \\
4 & $\begin{array}{c}\text { It is tax on value, which the supplier adds to } \\
\text { goods and services before selling them }\end{array}$ & 216 & 16 \\
5 & $\begin{array}{l}\text { It is tax paid for the services } \\
\text { received from public utilities }\end{array}$ & 72 & 6 \\
6 & It is simply value added tax & 585 & 44 \\
& & 1341 & 100 \\
\hline
\end{tabular}

Source: Authors (2013). 
they know the various forms of VAT in practice. However, no one of the respondents could give correct forms of VAT in practice, namely, the consumption, the income and the gross product types of VAT. In fact only insignificant proportion of the professional men (6\%), Businessmen (2\%) and laymen (almost 6\%)could identified Modified Value Added Tax (MVAT) as the form of VAT which is being implemented in Nigeria. Attempt to know whether the respondents really understood the basic difference(s) between sales tax and VAT showed that 1143 respondents (78\%) did not know the differences between the sales tax paid and VAT. Table $\mathbf{5}$ presents what they considered as basic differences.

Although many of the respondents claimed to know VAT law in Nigeria, only $3 \%$ of the professional men could identify the name of the VAT law as VAT Decree Number 103 of 1993 . About 48\% of professional men, $50 \%$ businessmen and about 33\% of the laymen correctively identified the agency responsible for the administration of VAT in Nigeria as the Federal Board of Inland Revenue; others referred to the State Government, Federal Government or simply indicated that they did not know. Not many of the respondents (Professional men $6 \%$, Businessmen $2 \%$, and laymen $8 \%$ ) have seen a copy of VAT Decree before, either from their friends, Libraries, Newspapers, or personal readings whether in the quest to know tax position or personal inquiry or business demanded or professional examination requirement.

\section{Taxpayers Understanding of VAT Law}

We observed that the same professional men (6\%) claimed

Table 5. Taxpayers' perceived differences between Sales Tax and VAT.

\begin{tabular}{|c|c|c|c|}
\hline S/No. & Responses & No. & $\%$ \\
\hline I & $\begin{array}{l}\text { VAT is chargeable on goods bought while sales } \\
\text { tax is chargeable on goods sold }\end{array}$ & 774 & 68 \\
\hline 2 & $\begin{array}{l}\text { VAT is charged on many goods while sales tax } \\
\text { is charged on certain fair luxurious goods }\end{array}$ & 135 & 12 \\
\hline 3 & $\begin{array}{l}\text { VAT can easily be offset while } \\
\text { sales tax is not off Settable }\end{array}$ & 9 & 8 \\
\hline 4 & $\begin{array}{l}\text { VAT is on consumption and utility while sales } \\
\text { tax is on transfer of goods/services }\end{array}$ & 63 & 6 \\
\hline 5 & $\begin{array}{l}\text { It is easier to collect VAT on } \\
\text { imported goods than sales Tax }\end{array}$ & 36 & 3 \\
\hline 6 & $\begin{array}{l}\text { VAT is levied on all restricted } \\
\text { companies such as hotels }\end{array}$ & 27 & 2 \\
\hline \multirow[t]{2}{*}{7} & $\begin{array}{l}\text { VAT allows tax refund while } \\
\text { sales tax does allow tax Refund }\end{array}$ & 18 & 1 \\
\hline & Total & 1143 & 100 \\
\hline
\end{tabular}

Source: Authors (2013). to have seen a copy of VAT Decree also claim to have read and understood it. Only 3\% of these professional men could talk about the content of the VAT Decree. To determine how much of the VAT law was known by taxpayers, we decided to ask some specific questions. Only few respondents (Professional men 3\%; business $4 \%$ and laymen $2 \%$ ) could somehow describe who VATable person is. None of the respondents in any of the three groups could identify the exact number of categories of $\mathrm{V}$ Arable goods and services, which are 11 and 24 respectively. However, they were able to identify some of the VATable goods such as electronics, cigarettes, wine, manufactured and assembled goods, raw materials for industries, spare parts, Supermarket goods, motor vehicles, heavy equipment and tractors, including materials and office machines etc. Some of the commonly VATable services identified by respondents including banking services and hotel services. We observed that most taxpayers did not know that commercial vehicle spare parts are VAT exempt.

Some respondents (professional men 34\%, businessmen $27 \%$ and laymen $30 \%$ ) are aware that some goods and services are VAT exempt. All the goods mentioned as VAT exempt by taxpayers are actually so, except that some of the services which the taxpayers considered as VAT exempt are not really so. For instance the taxpayers considered water and electricity supply, banking services and legal services as VAT exempt. This is not correct particularly banking service. It is only the services rendered by the Community Banks, People's Bank and mortgage institutions that are VAT exempt but not commercial banking services. There were some services mentioned by the respondents like barbing and housewife services, which are not included in the list of VAT exempt services. The fact that these services were not included in the list of VAT exempt services shows the exhaustiveness of the list.

Further enquiry showed that only 34\% of the professional men, $24 \%$ of the businessmen and $28 \%$ of the laymen knew the application VAT rate (5\%). We further explored the understanding of the taxpayers, on other VAT related concepts such as input tax, output tax, tax credit, tax refund and who is a registered person and his responsibilities. We observed that most of the taxpayers were not familiar with these concepts. They could readily identify the responsibilities of a registered person. Few of the respondents (professional men 27\%, businessmen, $22 \%$ and laymen $21 \%$ ) were aware of some of the VAT related offences and their penalties. Some of the commonly mentioned VAT offences are furnishing of false documents and claims, evasion, failure to issue tax invoice, failure to register and obstructing VAT inspectors from carrying out their duties. 


\section{Tax Payer's Assessment of Impacts of VAT}

About $28 \%$ of the professional men, $39 \%$ of the businessmen and $43 \%$ of laymen knew that they purchased VATable goods or subscribed to VATable services. Others were not sure. Beside $4 \%$ of the businessmen, other respondents were not in the habit of keeping records of VAT they paid and hence it was not easy for them to determine the proportion of VAT in their total tax payment in a year.

The respondents were asked to consider the adequacy of flat VAT rate of 5\%, the equity in VAT distribution, as well as impacts of VAT on individuals, business organizations and Nigerian economy. Not many of them could speak confidently on the adequacy or otherwise of the current rate of $5 \%$. For those who considered it as inadequate (professional men 19\%, businessmen 46\% and laymen 5\%), they argued that the rate was too high and that it failed to differentiate between classes and income groups. They suggested that VAT rate should vary from the income group and that the range of VAT exempt goods and services should be expended. We also observed that many of the taxpayers could not rightly identify the correct distribution formula for VAT proceeds (See Table 1). It was difficult for the respondents to comment on the adequacy of the distribution formula. However, respondents could identify some impacts of VAT since its inception. The taxpayers could agree as to the gains of VAT to individuals and business organizations except the nation as a whole. The only indirect gain of VAT to individuals, which they identified, is the possibility of discouraging the consumption of harmful goods. But this point is arguable of course. The business organizations seem to make no gain or loss, as they could offset whatever they pay as input VAT against output VAT. But the nation seems to be gaining from VAT in terms of the increase in revenue. This view is evidenced by the revenue received by the Federal Government since inception of VAT as indicated in Table 2.

Some of the negative consequences of VAT on individuals, business organizations, and Nigerian economy as considered by the respondents are summarized below. To the individuals, VAT helps to reduce their disposable income and consequently reducing their volume of consumption of goods and services. Some of the negative consequences of VAT to the business organizations as recognized by the respondents are as follows:

1) The increase in the cost of doing business in Nigeria (i.e. increase in cost of production or sales);

2) Reduction in volume of sales;

3) Burden of rendering VAT returns: increase in record keeping activities and their associated costs;

4) Reduction in net operating income; and

5) Incidence of multiple taxation.
It was claimed that VAT had increased the general cost of living in Nigeria.

Finally, we examined what problems the respondents considered to be confronting the operation of the VAT system in Nigeria. Some of the problems of VAT system in Nigeria as outlined by the respondents are detailed below:

\section{a) Human Problems}

Some of the human problems bedeviling the VAT system in Nigeria include the following:

1) Failure of the VATable persons to register for VAT;

2) Dishonesty on the part of the registered person either by delaying remittance or failing to remit VAT proceeds collected; and

3) Possible diversions of VAT proceeds and inability to give proper account of what VAT proceeds have been used for.

b) Technical Problems

Some of the technical problems raised by the taxpayers include evidence of poor VAT collection, lack of enforcement and follow-up system by the administrators.

\section{c) Logistic Problems}

The respondents agreed that the failure of the Government and its relevant tax authority to adequately publicize VAT Decree are responsible for its poor understanding by the taxpayers.

The respondents however identified the roles they expect individuals, Non-Governmental Organizations (NGOs), tax authority and government to play in solving the problems. Some of these roles are considered below. Individual taxpayers are expected to increase their knowledge on tax education, imbibe the culture of tax records keeping, and learn to comply with VAT Decree etc. The NGOs could join governments in serious enlightenment campaigns on tax law and tax matters. They could help to ensure strict compliance with VAT Decree in their transactions; register and keep adequate necessary VAT records, and ensure prompt remittance of VAT proceeds. The Governments could help in ameliorating VAT association problems by doing the following things:

1) Employ competent and adequate staff to man the VAT section;

2) Educate the public on tax law and tax matters;

3) Provide attractive tax relief to individual taxpayer;

4) Be more dutiful and aggressive in tax collective and administration;

5) Enforce strict compliance with VAT legislation amongst the VAT registered persons;

6) Enforce prompt remittance of VAT proceeds by VAT registered persons;

7) Set up VAT monitoring team who will be going out on a regular basis to carry out on-the-field-assessment of compliance with the law.

The governments are also expected to embark on 
public tax education in general and VAT enlightenment campaigns in particular. The Governments should ensure that however VAT proceeds, what collected from the VATable persons should be judiciously utilized so that the public commitment and loyalty to tax payment could be enhanced.

The observance of constitutional duties of tax compliance by citizens is predicated to the extent of their awareness and understating of tax laws. From our study, we observed as follows:

1) That the majority of Nigerian taxable persons is quite aware of the operations and knew that VAT law exists but many have never seen a copy nor talk, read and understand it. This is perhaps responsible for the difficulty of understanding the technical concepts contained in VAT law;

2) There is no remarkable difference in the knowledge of VAT law by the businessmen and professional men from those of laymen. We could conclude that the present form of general education does not guarantee tax education. Most of the professional men in this study could not demonstrate better understanding of the VAT law than Businessmen and laymen;

3) That poor understanding of various tax laws by taxpayers could be responsible for the high magnitude of their non-compliance.

Various suggestions were made on how to improve the level of awareness and general understanding of the taxpayers on any new tax law. The roles of the individuals, business organizations, NGO's and Government in improving the general tax education amongst the citizens in Nigeria were considered.

In conclusion, we believe, it follows that inclusion of tax education into our national education curricular, particularly from the secondary school level to the higher institutions of learning, will help greatly to improve the citizens' general understanding of various tax laws and matters. The legal drafting of the tax laws should be made less technical, having in mind the level of understanding of the taxpayers. Attempts should be made to popularize tax laws as soon as they come out and from time to time, efforts should be made to make copies of various tax laws readily available to members of the public. The need to promote the habit of keeping tax records by various taxpayers, including the individual, cannot be overemphasized. Currently, individual taxpayers do not keep their tax records and hence might not even know what proportion of their total tax is made up of VAT. Tax education could inculcate this habit of taxpayers, as it would increase the magnitude of voluntary tax compliance, decrease the incident of various tax offences inadvertently committed by individual taxpayers, and consequently enhance the revenue generation capability of taxation.

\section{REFERENCES}

[1] O. Akanle, "The Government, the Constitution and the Taxpayer,” In: M. A. Ajomo and O. Adanle, Eds., Tax Law and Tax Administration in Nigeria, Nigerian Institute of Advanced Legal Studies, IntecPrinters Ltd., Ibadan, 1991.

[2] J. M. Bickely, “The Value Added Tax: Concepts, Issues, and Experience," In E. A. Ogundele, Ed., Value Added Tax: Theory and Practice, University of Lagos Press, Lagos, 1996.

[3] O. Oldman and L. V. Woods, "Would Shifting Emphasis to a VAT System Relieve Tax Compliance Problems?” In: E. A. Ogundele, Ed., Value Added Tax: Theory and Practice, University of Lagos Press, Lagos, 1996.

[4] Statement of Standard Accounting Practice (SSAP) No. 5 VAT Decree No. 102, Government Printer, Lagos, 1993.

[5] A. Shenk, "Value Added Tax: Does This Consumption Tax System?” Virginia Tax Review, Vol. 7, No. 2, 1987, pp. 207-257.

[6] V. O. Obadagbonyi, "The Impact of Value Added Tax (VAT) on the Nigerian Economy,” B.Sc. Project, Department of Accounting, University of Benin, Benin City, 1996.

[7] E. A. Ogundele, "Value Added Tax: Theory and Practice,” University of Lagos Press, Lagos, 1996.

[8] Federal Inland Revenue Service, 1997.

[9] E. E. Owo, "The Perception of Nigerian Businessmen to Value Added Tax VAT)," B.Sc. Project, Department of Accounting, University of Benin, Benin City, 1996.

[10] J. J. Omoluru, “Contribution of Value Added Tax (VAT) to Total Federally Collected Revenue in Nigeria (19941998)," B.Sc. Project, Department of Accounting, University of Benin, Benin City, 2000.

[11] A. E. Ekhibise, "Value Added Tax Administration in the Manufacturing Industry: A Case Study of Bendel Feeds and Four Mill Limited,” B.Sc. Project, Department of Accounting, University of Benin, Benin City, 1997.

[12] S. I. Oyakhire, "Problems and Prospects of Value Added Tax (VAT) in Nigeria,” B.Sc. Project, Department of Accounting, University of Benin, Benin City, 1997.

[13] T. S. Ede, "Value Added Tax (VAT): Assessment of the Level of Understanding of the Provisions and Operations of the VAT Law Amongst Professional men in Nigeria," B.Sc. Project, Department of Accounting, University of Benin, Benin City, 1998.

[14] B. Onokevbagbe, "The Legal Framework of Value Added Tax (VAT) in Nigeria: A Perception of Tax Consultants," B.Sc. Project, Department of Accounting, University of Benin, Benin City, 1999.

[15] O. M. Osazuwa, “The Impact of VAT on Buying Behaviour of Consumers of VATable Supermarket Goods in Nigeria,” B.Sc. Project, Department of Accounting, University of Benin, Benin City, 200.

[16] S. A. Adereti, M. R. Sanni and J. A. Adesina, "Value Added Tax and Economic Growth in Nigeria,” European Journal of Humanities and Social Sciences, Vol. 10, No. 1, 2011, pp. 456-471. 
[17] A. A. Onaolapo, R. J. Aworemi and O. A. Ajala, “Assessement of Value Added Tax and Its Effect on Revenue Generation in Nigeria," International Journal of Business and Social Science, Vol. 4, No. 1, 2013, pp. 220-225.
[18] C. E. Umeora, “The Effects of Value Added Tax (VAT) on the Economic Growth of Nigeria,” Journal of Economic and Sustainable Development, Vol. 4, No. 6, 2013, pp. 190-201. 